\title{
Erratum to: Letter from the Editor
}

Jonathan J. Li

Published online: 8 February 2011

(C) Springer Science+Business Media, LLC 2011

\section{Erratum to: HORM CANC}

\section{DOI 10.1007/s12672-010-0064-0}

Laszlo Radvanyi's name was spelled incorrectly in the listing of Breast Cancer Speaker Presentations. The correct spelling is: Laszlo Radvanyi.

The author regrets the error.

The online version of the original article can be found at http://dx.doi. org/10.1007/s12672-010-0064-0

J. J. Li $(\bowtie)$

The University of Kansas Medical Center,

Kansas City, KS, USA

e-mail: jjli0622@gmail.com 